\title{
CODE SWITCHING IN ARTICLES IN THE JAKARTA POST
}

\author{
Maria Gaudensia Bria ${ }^{1}$, Marselus Suarta Kasmiran ${ }^{2}$, Barli Bram ${ }^{3}$ \\ ${ }^{1,2,3}$ English Education, Sanata Dharma University, Indonesia \\ Corresponding author's e-mail: barli@usd.ac.id
}

\begin{abstract}
This paper explored code switching between English and Indonesian in articles in the daily newspaper The Jakarta Post. Data were collected from six articles published in The Jakarta Post. The code switching data were analyzed to determine the reasons for the writers to switch codes. Results showed that there existed five reasons for code switching, namely "lack of one word in either language, one wants to make a point, some activities have only been experienced in one of the languages, some words are easier, more distinguishable and easier to use in one of the languages, and the speaker has difficulty in expressing oneself: expressing group identity". Related to the educational field, it is expected that the results will be beneficial for English teachers or lecturers to be more aware that sometimes they cannot avoid using code switching because translating some Indonesian words into English will lose the essence of the meaning.
\end{abstract}

Keywords: code switching, critical discourse, newspaper, The Jakarta Post

\section{INTRODUCTION}

Nowadays, people are more multilingual although English is the main spoken language in the world. The latest research reports from Pew Research Center said that Arabic was the fastest growing language in the UK, with a total of 1.1 million speakers and Spanish followed in second place. In the UK itself, people have now become more multilingual, with roughly 300 languages spoken in schools in London. People can communicate through various languages, mixed languages, without having any trouble (Aryasatya, 2017).

Mixed languages or code switching could be found easily since it has become common in this multilingual era. For Indonesians, Adhalia (2016) argued that people usually do code switching because the code switching becomes one of the lifestyles (Adhalia, 2016). She added that people could use code switching since some Indonesian jokes would be ruined if they were translated into English. Setiawan (2016) added that code switching is commonly used in business context. The use of 
the code switching may imply that Indonesian people still discover the lack of local words to translate the terms.

This paper focused on code switching in articles in The Jakarta Post since the researchers discovered that there were still few studies on code switching in an Indonesian newspaper. However, a newspaper was common for businesspeople and foreigners and also commonly used for well-educated people. Furthermore, it could also be used for authentic materials in the classroom since The Jakarta Post is common for learners in Indonesian schools. In this paper, the research question was formulated as follows: What are the purposes of using code switching in articles in The Jakarta Post?

In the following, the researchers discussed the contexts and purposes of code switching involving English and Indonesian. In our daily lives, language is a means for human beings to communicate with each other, to relate with each other. English as an international language is being learned in almost all countries in the world. In Indonesia, it is, however, very rare to find people speak English, in terms of social interaction. We can just find Indonesian people speak English in schools. We can also find others speak English because of the situation, for example, the presence of a foreigner in the communicative community, or in the family that has a cross-culture marriage, between an Indonesian and a Canadian, for example. English for Indonesians is a foreign language, and besides Indonesian as our national language, almost every Indonesian speaks her or his own mother tongue, such as Javanese and Dayaknese. The use of English and Indonesian may be referred to as bilingual. The use of two languages may make communication more effective and meaningful, and this strategy of communication is called code switching.

In learning English as a foreign language, we cannot avoid the process of trying to understand each other's language. To assist other language speakers and readers or listeners understand the functions, types, and reasons for using the switching, Crystal (1987) states that "switching commonly occurs when individual wishes to express solidarity with a particular social group." Code switching is not a language interference, on the extent of adding to the speech. It is used due to the inability of a 
person in expressing oneself; code switching helps the speaker continue the speech. Sociolinguistics has frequently dealt with studying speech communities where language is multiple and there will be a phenomenon of dealing with an assorted language.

Crystal (1987) states that there are three reasons for a speaker to use code switching, namely, first, "the speaker has difficulty in expressing oneself, so the speaker must use other words that fill up the lack of meaning of one's idea" (Crystal, 1987). Second, "code-switching commonly occurs when a speaker aims to express solidarity with others. It usually happens with cross culture married family" (Crystal, 1987). Third, "code switching occurs when the speaker wishes to express one gratitude or feeling towards a monolingual speaker" (Crystal, 1987).

Cheng (2003) states that "there were some conditions when the code switching mostly appeared". Code switching mostly appears when these conditions exist:

"(1) lack of one word in either language

(2) some activities have only been experienced in one of the languages

(3) some concepts are easier to express in one of the languages

(4) some words are easier, more distinguishable and easier to use in one of the languages

(5) a misunderstanding must be clarified

(6) one wishes to create a certain communication effect

(7) one continues to speak the language latest used because of the trigger effect

(8) one wants to make a point

(9) one wishes to express group solidarity

(10) one wishes to exclude another person from the dialog" (Cheng, 2003).

Many studies have discussed code switching in written and spoken forms, such as blogs (Silva, 2013), social media (Kosoff, 2014), and speech (Lyu, Chng, \& Li, 2013; see also Modupeola, 2013; Mukti, \& Muljani, 2017). John and Dumaniq (2013) studied code switching in Malaysian newspaper advertisements. Setiawan (2016) discussed the types of code switching in Indonesian contexts. Setiawan (2016) stated that Indonesian people were most likely to use code switching in a business relationship. 
Table 1. List of English Words in Business (Setiawan, 2016)

\begin{tabular}{|c|c|c|c|c|}
\hline \multicolumn{2}{|c|}{ Insurance Company } & \multicolumn{3}{|c|}{ Quality Control Department of Telecommunication company } \\
\hline $\begin{array}{ll}\text { - } & \text { auto debit } \\
\text { - } & \text { board of director } \\
\text { - } & \text { realer/showroom } \\
\text { - } & \text { deputy director } \\
\text { - } & \text { early termination } \\
\text { - } & \text { history payment } \\
\text { - } & \text { joint finance } \\
\text { - } & \text { over credit }\end{array}$ & $\begin{array}{ll}\text { - } & \text { overdue } \\
\text { - } & \text { principle } \\
\text { outstanding } \\
\text { - } & \text { purchase order } \\
\text { refinancing } \\
\text { - } & \text { refund } \\
\text { - } & \text { semi lease back } \\
\text { - } & \text { take over } \\
\text { - } & \text { waive penalty }\end{array}$ & $\begin{array}{ll}\text { - } & \text { activity plan } \\
\text { - } & \text { annual report } \\
\text { - } & \text { application letter } \\
\text { - } & \text { date of hire } \\
\text { director of } \\
\text { administration } \\
\text { - } & \text { due date } \\
\text { - } & \text { gellow up } \\
\text { - } & \text { general affair } \\
\text { - } & \text { heavy equipment } \\
\text { - } & \text { management trainee }\end{array}$ & 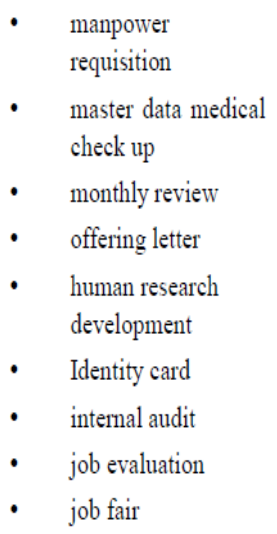 & $\begin{array}{l}\text { - } \\
\text { - } \quad \text { pending job job training } \\
\text { - } \text { quality control } \\
\text { - } \quad \text { recruitment } \\
\text { - } \quad \text { renewal contract } \\
\text { - } \quad \text { resignation letter } \\
\text { - } \quad \text { soft copy } \\
\text { - } \quad \text { team leader } \\
\text { - } \quad \text { weekly meeting } \\
\text { - } \quad \text { weekly report }\end{array}$ \\
\hline
\end{tabular}

Setiawan (2016) stated that the words (in Table 1) were commonly discovered in a business context. Indonesian people were likely to borrow the terms and used the words when they spoke in Indonesian. It happened for some reasons, such as the terminologies are already familiar to users; it is difficult to translate the words; if we insist on translating those words, it may take long explanations, and it is difficult to find the equivalent words in the local language. Setiawan (2016) added that there were some reasons for Indonesian people to use code switching, such as, it is used as it is more compact; it is more precise; it is more prestigious; and it is a starter or a stepping stone for a fuller use of the language.

\section{METHODOLOGY}

All the data in the study was collected from an online newspaper, thejakartapost.com. The Jakarta Post is a daily English language newspaper in Indonesia. The newspaper is owned by PT Bina Media Tenggara, and the main office is in the nation's capital, Jakarta. The Jakarta Post was established in 1983. The researchers chose to obtain the data from six articles in the newspaper because it has been long established and the six articles contained rich data of code switching. The newspaper also had a positive reputation since it followed cyber media news coverage guidelines which have been agreed by organizations of journalists and publishers. 
Furthermore, Tarrant (2008) states that the market of The Jakarta Post was businesspeople, well-educated Indonesian people, and foreigners. The Jakarta Post features an online newspaper and weekend newspaper. The researchers collected the data from the online version of the newspaper considering its easy and open access. The data for this study were presented in Table 2 below.

Table 2 Articles of The Jakarta Post

\begin{tabular}{|c|c|c|c|}
\hline No & Title of article & $\begin{array}{l}\text { Date of } \\
\text { publication }\end{array}$ & Web address \\
\hline 1 & $\begin{array}{l}\text { Can Kids Zaman Now } \\
\text { Fight Corruption Better? }\end{array}$ & $\begin{array}{l}\text { October } 30, \\
2017\end{array}$ & $\begin{array}{l}\text { http://www.thejakartapost.com/academia/ } \\
\text { 2017/10/30/can-kids-zaman-now-fight- } \\
\underline{\text { corruption-better.html }}\end{array}$ \\
\hline 2 & $\begin{array}{l}\text { Garden Library Brings } \\
\text { Books to Public Spaces in } \\
\text { Kupang Atambua }\end{array}$ & $\begin{array}{l}\text { October } 31 \\
2017\end{array}$ & $\begin{array}{l}\text { http://www.thejakartapost.com/life/2017/1 } \\
\text { 0/31/garden-library-brings-books-to- } \\
\text { public-spaces-in-kupang-atambua.html }\end{array}$ \\
\hline 3 & $\begin{array}{l}\text { Ratih Kumala: An } \\
\text { Instinctive, Detailed } \\
\text { Storyteller }\end{array}$ & $\begin{array}{l}\text { October } 16, \\
2017\end{array}$ & $\begin{array}{l}\text { http://www.thejakartapost.com/life/2017/1 } \\
\text { 0/16/ratih-kumala-an-instinctive-detailed- } \\
\text { storyteller.html }\end{array}$ \\
\hline 4 & $\begin{array}{l}\text { Bulak Fest 2017, Surabaya } \\
\text { Shooting Tourament } 2017 \\
\text { held in Surabaya }\end{array}$ & $\begin{array}{l}\text { November } \\
20,2017\end{array}$ & $\begin{array}{l}\text { http://www.thejakartapost.com/travel/201 } \\
\text { 7/11/20/bulak-fest-2017-surabaya- } \\
\text { shooting-tournament-2017-held-in- } \\
\text { surabaya.html }\end{array}$ \\
\hline 5 & $\begin{array}{l}\text { Tourism Ministry Holds } \\
\text { Human Resources } \\
\text { Training in Surabaya }\end{array}$ & $\begin{array}{l}\text { November } \\
24,2017\end{array}$ & $\begin{array}{l}\text { http://www.thejakartapost.com/travel/201 } \\
\text { 7/11/24/tourism-ministry-holds-human- } \\
\underline{\text { resources-training-in-surabaya.html }}\end{array}$ \\
\hline 6 & $\begin{array}{l}\text { Will warung Indomie } \\
\text { become a relic of our time }\end{array}$ & $\begin{array}{l}\text { September } \\
25,2017\end{array}$ & $\begin{array}{l}\text { http://www.thejakartapost.com/life/2017/0 } \\
\text { 9/25/will-warung-indomie-become-a-relic- } \\
\text { of-our-time.html }\end{array}$ \\
\hline
\end{tabular}

This study wa qualitative research and the data were analyzed from the viewpoint of discourse. Gee (2011) states that "a language can help us to inform something to others". More than informing, a language also allows us to do things. From the point of view, the researchers interpreted the texts as an interpretation of social phenomena. Hence, the researchers classified the texts into themes and linked the texts to social contexts.

\section{RESULTS}

Based on the analysis, the researchers identified the following five reasons for the writers to switch codes in the six articles published in The Jakarta Post newspaper. The five reasons were as follows: first, lack of one word in either language; second, 
one wants to make a point; third, some activities have only been experienced in one of the languages; fourth, some words are easier, more distinguishable and easier to use in one of the languages; and fifth, the speaker has difficulty in expressing oneself: expressing group identity. Each of the findings was discussed in the following section.

\section{DISCUSSION}

The five reasons for code switching in the six articles in The Jakarta Post are discussed below. The first reason is "Lack of one word in either language", as in the following.

[1] Additionally, the locals also need to learn about Sapta Pesona, an understanding of security, orderliness, cleanliness, freshness, beauty, friendliness and memories (JP, Nov, 24/17).

There is no word or phrase which can precisely express the meaning of the phrase sapta persona in English. It is part of the limitation of the writer of The Jakarta Post and as a result, one needs to explain it in English for English speaking readers to understand and know the meaning of the phrase.

[2] When it comes to the food scene, several must-try local dishes in the capital city of East Java are Jancuk Fried Rice, Klopo Ondomohen Satay, Rawon Setan, Lontong Balap and Soto Ayam Lamongan Cak Har (asw) (JP, Nov, 20/17).

In data 2 , the point is still similar to data 1 , where the writer has no specific equivalence to refer to or replace the words because those are special foods in Indonesia.

[3] Let's move to Indonesia -- Bandung in West Java. It's very easy to find small stalls selling noodle, tea, and coffee - all instant. These stalls are locally known as warung Indomie or warmindo for short. To call Indomie popular is an understatement since the brand name has become synonymous with "instant noodle (JP, Sept 25/17).

Data 3 also shows a similar point to data 1 and 2 above. If they are translated into English, Indonesian readers might lose the essence of the familiar Indonesian terms. 
The vocabulary items appear to be specifically common Indonesian, and not in another language.

[4] A total of 400 people took part in the tournament that was divided into four categories: tembak reaksi, tembak target, AA IPSC and hunting. Surabaya regional secretary Hendro Gunawan said that the event aimed to foster shooting athletes in Surabaya and promote tourism in Surabaya (JP, Nov, 20/17).

In data 4, the point is similar to point number two of Cheng's (2003) proposals, namely, some concepts are easier to express in one of the languages. It can be translated into English, but the sense of the translation might sound strange to Indonesian readers. It will be difficult to understand the meaning (of the translated version) because the original expression is a well-known term in the Indonesian athletic field.

The second reason for the code switching is "One wants to make a point", as in the following.

[5] Suppose you are walking to an Indonesian restaurant with a friend. You both sit at a table before taking a glimpse at bottles of sarsaparilla and kerupuk (deep fried crackers) sitting atop it. You might not think too deeply about them (JP, Oct,16/17).

The word krupuk is mentioned by the writer to emphasize the meaning of the object to the readers, especially non-Indonesians, to explain the meaning of what is 'krupuk' itself and emphasize that object that the novelist is using as the simple object of her writing. The reason here is the writer finds difficulty expressing the word directly in English. However, one cannot do anything because the word is the focus of the discourse of the writer's goal in writing.

[6] When I looked at this, I became curious. Why was this drink branded Badak[rhino]? Why have I rarely seen this thing being sold in the marketplace?"(JP, Oct,16/17).

Again, in data 6, Ratih Kumala in the interview refers to the object of the writing, using the word badak to emphasize the object of her idea, which she found unique for her to make an inspiration for her writing. She mentions badak as solidarity to the 
interviewer and also Indonesian readers. Thus, as an Indonesian Ratih mentions badak to express herself as an Indonesian in the story or her writing.

[7] Indonesia's young generation of those currently under 30 is the centre of attention, as evident with the popularity of the meme titled kids zaman now (kids these days)( JP-Oct,30/17).

The word zaman is stylish for young people who insert the word in a popular English expression. This shows that young people or teenagers use many special vocabulary items to make their communication sound interesting and modern.

[8] Another treat commonly found in these stalls is soda gembira, literally happy soda, referring to the bubbles produced when condensed milk meets with soda, which race to the top - almost like they are dancing (Nov, 23/17).

The beverage soda gembira is popular among Indonesians because of the main characteristic of the beverage, namely to make people gembira or happy.

The third reason is "Some activities have only been experienced in one of the languages", as in the following.

[9] She draws inspiration from everyday objects, such as kretek (clove cigarette), the subject of her novel Gadis Kretek (Cigarette Girl), originally published in Indonesian in 2012. The English translation of the book by Annie Tucker was recently published by United Kingdom publishing house Monsoon Books Ltd. this year ( JP, Oct,16/17).

The subject of the writing of Ratih Kumala is still the focus but the meaning is quite different. She uses the phrase gadis kretek to emphasize the characteristic of gadis kretek which refers to the Indonesian situation, environment, the habit, lifestyle of simple people. It can directly be translated into English, but the English version might cause the original gadis kretek lose its essence.

The fourth reason is "Some words are easier, more distinguishable and easier to use in one of the languages", as in the following.

[10] A literacy activist group, LEKO, in Kupang-NTT provides free books in Taman Nostalgia Kupang every Saturday afternoon in the park. They bring their own books and display them on a floor mat. (JP, Oct, 31/17) 
In the statement above, the sentence is using "taman". In fact, Taman Nostalgia is the name of a place. Taman means; garden. The writer here does not translate directly taman to garden, instead of garden nostalgia but taman nostalgia. It is to emphasize, for the readers that taman itself refers to Indonesian language, it means the garden it self is in Indonesia, and for the Indonesian people who are familiar to this garden will not be confused about it.

The fifth reason is "The speaker has difficulty in expressing oneself: Expressing group identity (Ansar, 2017), as in the following.

[11] The funds have further been disbursed to the Garuda Putih 042 Military Resort Command (Korem), which got Rp 298.1 million; the Jambi Police (Rp 232.8 million); the East Tanjungjabung regency administration ( $R p 481.2$ million) $(J P, O c t, 19 / 17)$

\section{[12] The Corruption Eradication Commission (KPK) (JP, Nov, 23/17)}

In data 11 and 12, the reason for using an acronym and abbreviation is that the original abbreviation or acronym appears difficult to be translated into English, the target language; the original terms Korem and $K P K$ in Indonesian are considered more familiar for the readers of The Jakarta Post.

\section{CONCLUSION}

The researchers concluded that in some contexts, the writers of The Jakarta Post can use words or terms in English, but the essence of the meaning of the original versions will lessen, especially for Indonesian readers, who know Indonesian cultures, habits, and environment. In one unique culture and language, some words cannot be changed with another terms or words easily. In the six articles, the researchers identified five reasons for writers of The Jakarta Post to switch codes. For the educational field, the study results suggest that teachers need to switch codes to let the students understand better in their communication in general and in the learning teaching activities in particilar. 


\section{REFERENCES}

Adhalia, K. (2016, February 2). Love \& friendship: Code switching. The Jakarta Post. Retrieved from: http://www.thejakartapost.com/news/2015/12/08/lovefriendship-code-switching.html

Ansar, F. (2017). Code switching and code mixing in teaching-learning process. English Education: Jurnal Tadris Bahasa Inggris, 10(1), 29-45. doi:https://doi.org/10.24042/ee-jtbi.v10i1.873

Aryasatya, R. (2017, January 19). Monolingual bias and English language education in Indonesia. The Jakarta Post. Retrieved from: http://www.thejakartapost.com/academia/2017/01/09/monolingual-bias-andenglish-language-education-in-indonesia.html

Cheng, K. K. Y. (2003). Code-switching for a purpose: Focus on pre-school Malaysian children. Multilingua, 22(1), 59-78.

Crystal, D. (1987). The Cambridge encyclopedia of language (Vol. 1988). Cambridge: Cambridge University Press.

Gee, J. P. (2014). An introduction to discourse analysis: Theory and method. London: Routledge.

John, D.A.F., \& Dumanig, F.P. (2013). Identity construction and code switching in English newspaper advertisements. SEARCH: The Journal of the South East Asia Research centre for Communications and Humanities, 5(1), 57-71.

Kosoff, Z. (2014). Code-switching in Egyptian Arabic: A sociolinguistic analysis of twitter. Al-Arabiyya: Journal of the American Association of Teachers of Arabic, 47(1), 83-99.

Lyu, D. C., Chng, E. S., \& Li, H. (2013, May). Language diarization for code-switch conversational speech. In Acoustics, Speech and Signal Processing (ICASSP), 2013 IEEE International Conference on (pp. 7314-7318).

Modupeola, O. R. (2013). Code switching as a teaching strategy: Implication for English Language teaching and learning in a multilingual society. IOSR Journal of Humanities and Social Science, 14(3), 92-94. https://doi.org/10.9790/1959$\underline{1439294}$

Mukti, T., \& Muljani, R. (2017). Code switching in the instructions of English language education study program lecturers. LLT Journal: A Journal on Language and Language Teaching, 19(1), 46-60. Retrieved from https://ejournal.usd.ac.id/index.php/LLT/article/view/311/266

Setiawan, D. (2016). English code switching in Indonesian language. Universal Journal of Educational Research, 4(7), 1545-1552. 
ANGLO-SAXON, VOL. 10, NO.2 : 253-263

Desember 2019

P-ISSN 2301-5292

E-ISSN 2598-9995

Svendsen, E. (2014). The influences of Code-switching in the Second Language

Classroom in connection to language development. Retrieved from https://muep.mau.se/bitstream/handle/2043/18110/Svendsen\%2C\%20Emelie.pdf? sequence $=2 \&$ is Allowed $=y$

Tarrant, B. (2008). Reporting Indonesia: The Jakarta Post story. Jakarta: Equinox Publishing. 